\title{
Zofía Kulesza
}

\section{KAPLAN I DUCHOWY KIEROWNIK LUDZKICH SUMIEŃ}

Zabieram głos jako ta, która miała szczęście przez piętnaście i pół roku korzystać w konfesjonale $z$ kapłańskiej posługi ks. dra Wojciecha Danielskiego. Kiedyś ks. Danielski powiedział o jednej ze swych penitentek: ,To jest zakonnica w każdym calu". Sądzę, iż tę sparafrazowaną charakterystkę można odnieść do jej Autora i stwierdzić, że ks. Danielski był kapłanem w każdym calu.

$\mathrm{Na}$ podstawie własnych obserwacji ośmielam się postawić hipotezę, iż ks. Danielski uznawał zasadę, że kapłan - to przede wszystkim szafarz łaski. Dlatego ulubionym polem Jego kapłańskiej działalności były: ołtarz, ambona i konfesjonal.

Każdy, kto choć raz uczestniczył w Ofierze Eucharystycznej sprawowanej przez ks. Danielskiego, wie, jak czynił to $z$ wielką pobożnością. $\mathrm{Z}$ zamiłowaniem także głosił Słowo Boże. Pamiętam okres formowania się tradycji wygłaszania codziennej homilii podczas koncelebry o $7.30 \mathrm{~W}$ kościele akademickim KUL. Nieraz kilka dni z rzędu, mówił je ks. Wojciech, prawdopodobnie w zastępstwie głównych celebransów, którzy być może nie byli przygotowani do ich wygłaszania. W tym samym czasie niemal codziennie, zasiadał ks. Danielski w konfesjonale. W takich też okolicznościach zrodzilo się Jego duchowe ojcowstwo w stosunku do mnie.

Mówiąc o ks. Danielskim jako spowiedniku, pragnę na wstępie podkreślić Jego wielką kulturę osobistą i szacunek dla człowieka. Nawet wówczas ,gdy zdarzyło Mu się spóźnić na umówiona godzinę, przepraszał zawsze za to i podawał powód, np. iż musiał przedłużyé konsultację, bo. przyjechał ktoś z daleka.

Ks. Danielski był spowiednikiem wymagającym. Nie tolerował nawet. drobnych 'uchybien, ale upominał, prostowal, radził i proponowal konkretne rozwiązania. To wszystko czynił jednak z wielką lagodnością i prawie prosząco. Jego nauki sakramentalne były zwięzłe, ale zawsze poszerzone poleceniem rozważenia, w duchu pokuty, fragmentu Pisma św., dostosowanego do duchowych potrzeb penitenta. Najczęściej był to jakiś. z psalmów lub rozdział z listów apostolskich, zwłaszcza św. Pawła. Jako liturgista stosował ks. Danielski w całej rozciągłości odnowiony obrzęd sakramentu Pojednania. Pokochałem ten święty dialog tak, że ilekroć musiałam spowiadać się przed innym kapłanem, który nie uwzględniał odnowionego rytu, to odczuwałam poważne zubożenie tego przeżycia sakralnego.

Posługę kapłańską Ojca Danielskiego bardzo ceniłam i uważałam ją w moim życiu za wielki dar Boży. Miałam jednak świadomość Jego rozlicznych obowiązków. Byłam więc gotowa $z$ tej wartości zrezygnować, by odciążyć Ojca. Tę gotowość zgłaszałam parokrotnie ks. Wojciechowi, lecz. zawsze odpowiadal, że ma dość czasu, by mnie także służyć. Taka postawa Ojca Wojciecha wyplywała $z$ wielkiego poczucia odpowiedzialności za ludzi, których Pan powierzył Jego kapłańskiej pieczy. Ujawniło się to dobitnie w czasie ostatniej choroby ks. Danielskiego.

Po przerwie wakacyjnej dowiedziałam się $z$ opóźnieniem o chorobie Ojca i Jego pobycie w szpitalu. Gdy zadzwoniłam, by ustalić czas odwiedzin, ucieszył się wyraźnie i sam wyznaczył dzień. Przy okazji także swoim szyfrem, jakiego używał, gdy umawialiśmy się telefonicznie na sakramentalne spotkania, oznajmił, iż będzie szansa spowiedzi. Skorzystałam z niej w szpitalnej kaplicy. Uderzył mnie wówczas niezwykły spokój i większa niż zwykle dobroć, które emanowały z Ojca. Sama nauka sakramentalna, której udzielał, byla już przygotowaniem do rozstania. Wskazywało na to także dyskretne podsunięcie ewentualnego następcy. Po spowiedzi Ojciec rozmawiał krótko. Gdy odchodził zatrzymał się na mo- 
ment, odwrócił i powiedział: „Proszę dowieázieć się na Sławinku, czy nadal będę w szpitalu. Jeśli tak, to zapraszam za jakieś dwa tygodnie". Po upływie tego czasu i upewnieniu się o dalszym pobycie Ojca w szpitalu, poszłam Go odwiedzić, by spełnić Jego życzenie. Zaraz po wejściu do pokoju Chorego, zauważyłam znaczne pogorszenie stanu Jego zdrowia. Mimo to Ojciec oznajmił, że pragnie mi służyć swą pomocą. Zaczęłam tłumaczyć, iż nie chciałabym Go męczyé. Ale On powiedział poważnie: „Uważam, że powinienem, zwłaszcza że wkrótce wyjeżdżam".

Po spowiedzi zapewniałam Ojca o modlitwie, w Jego intencji. Podziękował za nią i odpowiedział: „20 listopada powinienem byé w Sandomierzu, a potem w domu. Proszę zadzwonic na Sławinek". Była to ostatnia próba umówienia się na sakramentalną spowiedź, która niestety, już się nie odbyła.

Kiedy dziś poszukuję lapidarnego sformułowania, jakie podsumowałoby przytoczone fakty i scharakteryzowało tę świetlaną postać świątobliwego kapłana, to jedno określenie nasuwa mi się nieodparcie: był to Pasterz dobry.

Lublin

ZOFIA KULESZA

\section{KSIĄŻKI NADESŁANE DO REDAKCJI}

1. Bar Joachim Roman OFMConv, Poradnik kanonicznego prawa zakonnego, W-wa 1986, ATK, s. 154.

2. Barcik Józef Symeon OFMConv, Kalwaria Pacławska, W-wa 1985, ATK, s. 349.

3. Bielecki OMI, Wybrane zagadnienia psychologii, W-wa 1986, ATK, S. 208.

4. B ończyk Norbert ks., Góra Chełmska (Góra św. Anny - wspomnienia z roku 1875), wyd. III, Opole 1985, Wyd. św. Krzyża, s. 196.

5. Jabłońska-Deptuła Ewa, Trwanie $i$ budowa. Hororat Koźmiński, kapucyn, W-wa 1986, Wyd. SS. Loretanek, s. 316.

6. Jaskóła Piotr ks., Bóg z nami - Ekumeniczno - dogmatyczne studium chrystologii Johna Arthura Thomasa Robinsona, Lublin 1986, KUL, s. 188.

7. Läp ple Alfred, Od egzegezy do katechezy, t. 1-2. Przekł. B. Bialecki. W-wa 1986, PAX, s. 427-514.

8. Lisowska-Niepokólczycka Anna, Jest tu chłopiec, t. II: Zakwitk szkarłatny kwiat, W-wa 1986, ATK, s. 319.

9. Mert on Thomas, Modlitwa kontemplacyjna. Przekł. M. Dybowski OP, Poznań 1984, „W drodze”, s. 108.

10. Męka Jezusa Chrystusa, praca zbiorowa pod red. ks. F. Gryglewicza, Lublin 1986, KUL, s. 271. 